\title{
Progression of Financial Reporting in Czech Republic and its Regulation"
}

\author{
Jana IŠTVÁNFYOVÁ* - Ladislav MEJZLÍK ${ }^{* *}$ \\ Jiří PELÁK $K^{* * *}$
}

The article discusses conceptual issues in developing national accounting framework. In 1989, the Czech Republic was a country emerging from an economy without private ownership and in 2004, the same country joined the European Union with a developed system of regulation of financial reporting for private businesses based on International Financial Reporting Standards (IFRS). Presenting the state of accounting today the article demonstrates (in) sufficiency of time to evolve complex accounting standards and legislation within a 15-year timeframe (for some interim steps see Černý, Hora, 1998). The article describes the Czech general accounting background and considerations associated with the adoption of IFRS in the conditions of Czech transition economy. The comparison of IFRS with Czech national legislation contrasts the two different views of these two systems. Even the big companies that have implemented IFRS are strong influenced by Czech accounting rules due to persisting tax objectives contained in national legislation. In addition to addressing the accounting legislation, the article also deals with changes within the accounting and audit professions, which organizational structure had to be built from scratch as there were no traditions to follow. It is no surprise that there are still doubts and discussions what should be the role of accounting in the young economy.

\# This article was prepared as a result of the research plan Development of Financial and Accounting Theory and its Application in Practice from Interdisciplinary Point of View (registered number MSMT6138439903).

" Dr. Ing. Jana Ištvánfyová - senior lecturer; Department of Financial Accounting and Audititing, Faculty of Finance and Accounting, University of Economics Prague, Winston Churchill Sq 4, 13000 Prague 3, Czech Republic; <istvanfy@vse.cz>.

** Doc. Ing. Ladislav Mejzlík, PhD. - head of Department of Financial Accounting and Audititing, Faculty of Finance and Accounting, University of Economics Prague, Winston Churchill Sq 4, 13000 Prague 3, Czech Republic; <mejzlik1@vse.cz>.

*** Ing. Jiř́i Pelák, Ph.D. - senior lecturer; Department of Financial Accounting and Audititing, Faculty of Finance and Accounting, University of Economics Prague, Winston Churchill Sq 4, 13000 Prague 3, Czech Republic; <pelak@vse.cz>. 
Czech law still emphasizes its significance for tax purposes but both academy and professionals tend to stress the concept of financial accounting. The article should give a brief overview of most important features that make Czech accounting unique. Mostly, the Czech peculiarities may be perceived as non-conceptual curiosity (for future development see Skálová, 2009). By describing all evolution steps the Czech accounting system has undertaken within last 15 years the authors want to demonstrate the extent of changes that took place is rather short time.

\section{Financial reporting}

\subsection{Requirements to the accounting information disclosure}

All entities that are registered by the Business Register (mainly all companies) are required to provide their statements to the Register. Then, the statements sent can be found at www.justice.cz if the Register has already digitalized them (if not, a personal visit is needed to gather hard copies of financial statements). Since January 1, 2007 all registered subjects are required to send an electronic PDF copy of their statements.

Publicly traded companies are required to send their annual and semiannual reports to Czech National Bank. They can be found at www.sec.cz. Besides, the companies have to publish them. In all cases they use the Internet to make their statements accessible.

The financial statements are also to be attached to a tax report filled with Tax authorities.

There is also a requirement to provide some financial data to Czech Statistical Agency. Not all companies are required to do so; it depends whether the Agency includes them to its surveys. Unfortunately for companies, the Agency does not collect financial statements but it rather requires data to be filled in their specific forms. XBRL (eXtended Business Reporting Language) is not used.

\subsection{Forms of financial reporting}

All entities are required to prepare (a) balance sheet, (b) profit and loss statement and (c) notes to the financial statements which are to 
explain both statements more in detail. Moreover, accounting entities are allowed (not required) to prepare (d) a cash flow statement and (e) a statement of changes in equity.

Besides, obligatory audited companies have to present an Annual Report with comprehensive information about recent activities and trends.

Content and structure of the statements is defined by regulation 500/2002 Sb. (in case of common business) of the Ministry of Finance. Particularly, names and content of each line which can be found on a financial statement are set.

The layout is up to an accounting entity.

\section{Profit and Loss Statement}

There is a vertical income statement used. The statement as well as the profit is broken into three parts: operating, financial and extraordinary one.

Financial income is represented by interests, FX gains and losses or revaluation gains or losses on tradable securities. Extraordinary income includes result of events which happen very rarely or are extraordinary compared to normal business activities of an entity.

In the income statement the entity may choose between two approaches to expense classification: they can be broken according to their nature or their function. In latter case, expenses presented according to their nature must be disclosed in the notes to the financial statements. Compensations of revenues and expenses are not allowed.

\section{Balance Sheet}

The horizontal presentation is required. Assets are ordered according their liquidity starting with intangible assets and ending with cash. Both assets and liabilities are divided into long-term and short term categories.

Compensations of assets and liabilities are not allowed. Accruals and deferrals are presented separately apart from other assets and liabilities. One interesting point is that long-term receivables are presented among short term receivables. 


\section{Cash Flow Statement}

On the cash flow statements (in case the statement is prepared by an entity) cash flows are broken into three parts: operating, investment and financing parts.

Operating cash flow concerns money earned and spent in the course of normal activities. Also, it contains receipts and expenditures which can not be presented as cash flow from investing or financing activities.

Investing cash flow contains cash flows resulting from purchases and sales of fixed assets or activities such as providing money to third parties unless they are considered operating activities.

Financing activities are defined as activities which affect amount or structure of equity and long- (or sometimes short-) term liabilities.

The statement may be based on direct or indirect method of cash flow computing in its operating part. In case of investing and financing activities, the direct approach is used.

\section{Statement of Changes in Equity}

Rules concerning the statement of changes in equity are so short that they are cited below word by word: "The statement of changes in equity presents information about increases or decreases of equity items between two balance sheet dates. Accounting entities shall disclose dividends paid and resources which were used for that purpose."

\section{Footnotes to the financial statements}

Basically, footnotes shall contain additional information about assets, equity, liabilities and profit if such information is considered material. Besides, following information is required:

- Date, when the entity was set up, details about related parties, changes made to Business Register, description of the business structure, names of members of the board, etc.;

- List of subsidiaries with required details such as percentage of share in the subsidiary, amount of equity, amount of profit and loss, etc.; 
- Number of employees, employee service costs, payments made to management of company, board of directors and supervisory board (all together, not person by person);

- Credit lines with respective interest rates, business relationships to members of management;

- Accounting principles used for preparing the statements and the way the entity has applied them including exemptions if occur;

- Details about doubtful debts, provisions, deferred tax, liabilities due in five years or more, tax liabilities, etc.;

- Information about assets and liabilities which are not presented on the balance sheet (such as leased property or bank guarantees);

- Material events.

\subsection{Requirements to consolidated reporting}

The Act on Accounting allows preparing consolidated statements solely according to IFRS. In case an accounting entity does not choose this option it is required to follow the CAS rules for consolidated financial statements. However, requirements for consolidated reporting are similar to those of IFRS (except rules for business combinations, i.e. calculation and treatment of goodwill etc.). In case an accounting entity chooses to use IFRS rules for consolidations it must not end up with consolidated statements which would comply with IFRS because there is no requirement to transform the underlying individual statements to be conforming to IFRS.

\subsection{Coordination of statements by national standards and statements by IAS / IFRS}

Financial Statements prepared according to Czech Accounting Standards and those prepared in accordance with IFRS differs significantly. The national standard setter (Ministry of Finance) have not taken any actions in order to decrease a degree of incomparability between IFRS requirements and CAS requirements even if these two sets of accounting rules are applied in the Czech Republic simultaneously by different companies.

The exemptions (i.e. areas which may be considered comparable) are represented by rules for consolidated statements and, more or less, for cash flow statement. 
Examples of main conceptual differences follow:

- Revenue recognition (in CAS there are no rules at all);

- Lease (there is no difference between financial and operating lease);

- Business combination (the respective concept differs significantly according to Zelenka, 2006);

- Provisions (according to CAS, among provisions there are items presented which do not meet the definition of a provision according to IFRS);

- financial instruments (CAS have less detailed rules);

- interim financial reports (in CAS there are no rules at all).

Besides the areas mentioned, differences may be found literally everywhere (see also Kovanicová, 2005): in the area of PP\&E, Impairment of assets, receivables, liabilities, etc. Financial Statements prepared according to CAS contain usually more details than their counterparts prepared according to IFRS. On the other hand, comprehensive set of relevant details which are disclosed in notes to IFRS financial statements provide more information than CAS statements including notes eventually.

\section{National Standards and International Accounting and Financial Reporting Standards (IAS/IFRS) Implementation}

\subsection{Availability and list of national standards}

The main legal source is the Act on Accounting (No 563/1991). The Ministry of Finance issues regulations to give concrete form to rather general provisions of the Act. The regulation differs according to a field of business of an entity. Both Acts and regulations are published in Journal of Acts of the Czech Republic. The Journal (besides hard copies) is available at http://www.mvcr.cz (PDF format) or http://portal.gov.cz (HTML format which supports search engines). Accounting policies in detail are set by the Czech Accounting Standards (CAS) which are different for different kind of businesses in the same manner as the regulations. 
The Standards are set and issued by the Ministry of Finance. Standards do not have a power of a legal act. However, the Act on Accounting allows the Ministry to transfer the due process to another party. This possibility has never been put into effect. Formally, Czech Accounting Standards are not considered official law of the Czech Republic so that they are not published in Journal of Acts (see Note 2).

\subsection{The Chart of Accounts: characteristics and structure}

Entities have to follow a blueprint of a Chart of Accounts which is included in the regulation 500/2002. However, only grouping of accounts is set. Name of accounts as well as a number within a group can be chosen by an entity (for examples see Kovanicová, 2007)

Besides the blueprint for common business, there are separate ones for banks, insurance companies, non-profit organizations, government bodies etc.

There are two blueprints for expenses which can be broken down according to their nature or function. The vast majority of companies break their expense according to their nature. However, e.g. banks are required to break their expenses according to their function.

A list of groups of accounts can be found in the last chapter as an attachment.

\subsection{Application of IAS/IFRS in the country}

The Czech Republic as a member of the EU (since 1.5.2004) had to accept the regulation of the EU Commission regarding application of IFRS since 1 . January 2005. The accounting law had been in conformity with 4th, 7th and 8th Directive even long before the country joined the Union (see Žárová, 2006).

All companies publicly traded at EU capital markets are required to apply IFRS. There is no departure from that rule also in the Czech Republic. On the other hand, they are required to calculate profit according to Czech Accounting Standards regardless IFRS rules. The reason is that the income tax calculations follow up accounting profit. 
Non-publicly traded companies are required to follow Czech Accounting Standards and must not use IFRS even if they are subsidiaries of foreign or local companies which are required to present their consolidated accounts according to IFRS. In those cases, they prepare their financial statements according to Czech Accounting Standards and after that they transform the statements into those according to IFRS which are used for reporting purposes.

Czech Accounting Standards have a different philosophy from IFRS. Requirements of both systems are fully incompatible. Reporting according to Czech Accounting Standards and to IFRS give different figures. Consequently, enterprises can not be compared among each other or in a time row.

\section{Audit and Accounting Regulation}

Legal rules which handle accounting rules can be broken into few levels. The legal system regarding accounting illustrates. All rules (except IFRS) are set by the Ministry of Finance. The Act on Accounting is approved by the parliament. Czech Accounting Standards may be set by another body but it has never happen for lack of related legal rules. Basically, there are no legal or professional requirements specific for an accountant. In case an accountant works as entrepreneur he needs only to register with the Trade Supervisory Office similarly as all other entrepreneurs. For accountants who work as employees there are no rules at all except those imposed employers. If an accountant wants they can receive a certification from Union of Accountants which is similar to ACCA certification (see the chapter on professional organizations).

\subsection{Audit Regulation}

The audit legal framework is fully harmonized with acquis communautaire. Particularly, the profession of auditors, their rights and duties, basic principles of conducting audit as well as a status of the Chamber of Auditors are set by the Act on Auditors which conforms with the 8th EU directive on audit and its amendments.

However, the Act on Accounting sets when financial statements are required to be audited. In case of stock companies, they have to be audited when at least one of the following conditions is fulfilled: (a) asset 
book value exceeds CZK 40 mil., (b) turnover exceeds CZK 80 mil. or (c) number of employees exceeds 50 . The limited liability company has to fulfill at least two conditions in the two last years.

The Chamber of Auditors of the Czech Republic is an independent institution which is not supported from public sources. All auditors are members of the Chamber compulsory. To become an auditor it is required to pass 9 written exams and one final oral exam. The chair of a team of examiners (in case of the final exam) is a representative of the Ministry of Finance.

The Chamber of Auditors has implemented International Standards on Auditing (ISA) set by IFAC as well as its ethic code.

Auditors and their operations are controlled by the Chamber, particularly by its disciplinary board which is also in charge of setting penalties when rules are broken. The Chamber also requires their members (i.e. auditors) to take part in a so called "continuous learning process" for a specific number of learning hours every year.

\subsection{Accounting Regulation}

Accounting regulation is consistent with traditions of continental Europe. It is based on rules set by the government and approved by the parliament. There are many influences recognizable: German, French, IFRS and US-GAAP as well those coming from the time before 1989.

After 1989 the first Act on Accounting was set. A tax reform took place and as a result, accounting and tax rules were separated for the first time (however, the process has never finished in full extent).

The national standard setter is the Accounting Department of Ministry of Finance. The department is the author of all accounting rules in the Czech Republic.

After 1989, until then one group of preparers was divided into more groups. Consequently, accounting was adapted accordingly. Resulting major changes in accounting legislation are the following:

- In the first stage, in 1990, the single entry bookkeeping was introduced. Only entrepreneurs who were not companies and were 
not registered with a Business Register were allowed to use it. The single entry bookkeeping was focused on receipts and expenditures used as a base for income tax calculations.

- In the second stage, the single entry bookkeeping was excluded from accounting rules and was included into tax rules. The reason was that the single-entry bookkeeping did not provide sufficient information on financial position of a preparer and its true role was tax only. Instead, simplified double entry bookkeeping was introduced. The simplification was represented by dropping some more complex requirements, such as deferred tax calculations.

- In the third stage, since January 1, 2005 IFRSs were introduced based on EU regulation focusing on consolidated accounts of publicly traded companies.

As a result of the differentiation, today we can find the following four categories of preparers who are subject of different accounting policies:

\section{Level 1}

Large companies whose securities are publicly traded. The companies must follow IFRS for both bookkeeping and reporting purposes. Consequently, huge changes had to be made to their existing information systems. Changes particularly touched software, organizational structure, workflow, training of accountants etc. Companies do not have to present their financial statements according to Czech Accounting Standards anymore. On the other hand, for tax purposes they still have to follow Czech Accounting Standards.

\section{Level 2}

This level refers to small and medium enterprises from Accounting Act point of view. However, in practice also large companies might be involved; even larger (but not listed) than Level 1 companies. The parent company is usually the one which is listed; this leads to a rather complicated case because statutory accounts must follow the Czech Accounting Standards but the company reports to the parent in compliance with IFRS. Voluntary IFRS application by those companies is not allowed by law. Consequently, many technical questions are raised: what records are the primary ones, is it possible to prepare two high quality but based on different concepts reports (according to CAS and 
IFRS), do they have to have two sets of accounts or can they prepare the IFRS financial statements just by converting CAS financial statements?

\section{Level 3}

This level comprises small companies for whom accounting legislation allows large simplifications, because usually there are no external users of accounting information. Consequently, their financial statements are neither audited nor publicly presented.

\section{Level 4}

This level comprises business of the individuals for whom no accounting legislation exists and the rules for keeping their records in Tax Journal are prescribed by Income Tax Act. The main purpose of Tax Journal is to find out the taxable profit.

\subsection{Professional organizations of accounting and auditing}

- Chamber of Auditors of the Czech Republic (Komora auditorů České republiky - KACR)

The Chamber was established by law and the membership is obligatory for all auditors and auditing firms. The chamber performs supervision function over auditors' operations and organizes training courses (for more details see chapter Audit Regulation). The Chamber is a member of IFAC.

- Chamber of Tax advisors of the Czech Republic (Komora daňových poradců České Republiky - KDP CR)

The Chamber was established by law and the membership is obligatory for all tax advisors. The chamber performs supervision function over asdvisors' operations and organizes training courses.

- Czech National Accounting Board (Národní účetní rada - NÚR) Czech National Accounting Board is an independent association of:

- Chamber of Auditors of the Czech Republic;

- Chamber of Tax advisors of the Czech Republic;

- Union of Accountants;

- University of Economics Prague (Faculty of Finance and Accounting). 
The Board has no specific rights. The purpose of the Board is to support high level of proficiency and professional ethics of accounting profession. Main activity of the Board is giving expert opinions (so called "interpretations") on Czech accounting rules. The opinions have no legal status.

\section{Conclusion}

To conclude, fifteen years were not enough for settling down of national accounting regime. Major unsolved issues in the Czech national accounting system remain, including incomparability of Czech Accounting Standards (CAS) and IFRS. Both systems result from different concepts. Publicly traded companies must follow the IFRS, the rest follows CAS. Voluntary application of IFRS is not permitted. Transition from CAS to IFRS and vice versa has a big impact on ERP and reported numbers. As a result, the accounting data is not comparable.

CAS was created by Ministry of Finance when it transformed former legal rules into standards. The Act on Accounting allows standard setting by an authority independent from a state. That paragraph has never been applied. There is no conceptual framework, no professional institution and no funding and due process rules. The National Accounting Board mentioned above have no legal power to push through its interpretations.

When consolidated accounts are prepared and companies within a group are required to apply both CAS and IFRS, the consolidated statements must be prepared according to only one set of rules depending on rules for a parent company. In that case the statements prepared according to the different set of rules must be transformed.

Relationship between accounting rules and practice on one side and tax rules on the other side. Even if publicly traded companies are required to report according to IFRS they must calculate a profit according to CAS which serves as a base for tax calculations. In other words, the tax calculations are not independent from accounting profit.

\section{References}

[1] Černý, V. - Hora, M. (1998): Účetnictví bez tajemství. Praha, Grada, 1998. 
Ištvánfyová, J. - Mejzlík, L. - Pelák, J.: Progression of Financial Reporting in Czech Republic and its Regulation.

[2] Kovanicová, D. (2005): Finanční účetnictví - světový koncept. IFRS/IAS. Praha, Polygon, 2005.

[3] Kovanicová, D. (2007): Abeceda účetních znalostí pro každého. Praha, Polygon, 2007.

[4] Skálová, J. (2008): Nová výzva pro české účetnictví. In Procházka, D. - Korda, J. (eds.).: Sborník 9. konference studentů doktorského studia FFÚ. Praha, Oeconomica, 2008, s. 361-372.

[5] Zelenka, V. (2006): Goodwill. Principy vykazování v podniku. Praha, Ekopress, 2006.

[6] Žárová, M.(2006): Regulace evropského účetnictví. Praha, Oeconomica, 2006. 


\title{
Progression of Financial Reporting in Czech Republic and its Regulation
}

\author{
Jana IŠTVÁNFYOVÁ - Ladislav MEJZLÍK - Jiří PELÁK
}

\begin{abstract}
The development of a national accounting framework presents unique issues. A strong accounting system needs sufficient time to evolve. The influence of IFRS and of existing tax objectives of Czech accounting system increase the complexity and costs of implementing and monitoring the accounting rules. Given the short time between abandoning an economy based on public ownership and joining the European Union, Czech Republic made significant progress in development of its accounting regulation. The article addresses implementation of IFRS in the Czech Republic and describes the structure of accounting and auditing regulation which can be divided into four levels according to the reporting requirements set by the legislation. Major unsolved issues in the Czech national accounting system remain, including incomparability of Czech Accounting Standards and IFRS.

Key words: International Financial Reporting Standards (IFRS); Development of Czech Accounting; Joining the European Union; Underdevelopment of accounting; Implementation of IFRS into Czech Accounting Regulation.
\end{abstract}

JEL classification: M40. 